\title{
DIAGNOSIS DAN INSIDENSI PENYAKIT ANTRAKNOSA PADA BEBERAPA VARIETAS TANAMAN CABE DI KOTA BITUNG DAN KABUPATEN MINAHASA
}

\section{DIAGNOSIS AND INCIDENCE DISEASE ANTRACNOSE ON SOME VARIETIES OF CHILLI PLANT IN THE CITY OF BITUNG AND MINAHASA REGENCY}

\author{
M.M. Ratulangi1), Sembel, D.T.1), C.S. Rante1), M.F. Dien'1), E.R.M. Meray1), \\ M. Hammig2), M. Shepard2), G. (arner') dan E. Benson') \\ 1)Universitas Sam Ratulangi, Manado Indonesia \\ ${ }^{2}$ Clemson University, South Carolina, USA
}

\begin{abstract}
This study was carried out in the laboratory and in the field at City of Bitung, Districts of Minahasa. The cause of disease was studied in the laboratory and the percentage of insidence of disease was carried out in the field. Results showed that the cause of antracnose disease in North Sulawesi was Colletotrichum gloeosporioides (Penz.) Penz \& Sacc. in Penz (Cg). Computation of the antracnose disease insidence showed that variety white hot chili has the highest disease insidence which is $16.50 \%$ followed by green hot chili $10.13 \%$, and the lowest is curled chili which is $9.03 \%$. The different in this rate is affected by pathogen, host plant and the environment. Field observation showed that this disease has already spread at all chili plantation at the City of Bitung and District of Minahasa.
\end{abstract}

Keywords: Chili, antracnose, Colletotrichum gloeosporioides

\section{ABSTRAK}

Penelitian dilaksanakan di laboratorium dan di lapangan yaitu Kota Bitung dan Kabupaten Minahasa. Penelitian di laboratorium untuk menentukan jamur penyebab penyakit antraknosa, sedangkan di lapangan untuk mengetahui insidensi penyakit dengan menggunakan metode survey dan pengambilan sampel secara sengaja (purposive sampling) pada buah yang terserang penyakit antraknosa. Hasil penelitian menunjukkan bahwa karakteristik jamur penyebab penyakit antraknosa di Propinsi Sulawesi Utara adalah Colletotrichum gloeosporioides (Penz.) Penz \& Sacc.in Penz.(Cg). Hasil perhitungan Insidensi penyakit antraknosa menunjukkan bahwa varietas cabe rawit putih tertinggi yaitu $16,50 \%$ diikuti oleh varietas cabe rawit hijau 10,13\% dan terendah adalah varietas cabe keriting 9,03\%. Perbedaan tingkat ketahanan varietas ini dipengaruhi oleh faktor pathogen, tanaman inang dan lingkungannya. Kemudian dilihat dari lokasi pengamatan di beberapa Kecamatan di Kota Bitung dan Kabupaten Minahasa bahwa penyakit ini sudah tersebar merata disemua pertanaman cabe.

Kata Kunci: Cabe, antraknosa, Colletotrichum gloeosporioides

Eugenia Volume 18 No. 2 Agustus 2012 


\section{PENDAHULUAN}

Di Indonesia cabe merupakan salah satu jenis tanaman hortikultura yang penting dan dapat dibudidayakan oleh para petani. Sebagai komoditi hortikultura yang penting, cabe dapat ditanam mulai dari dataran rendah sampai dataran tinggi, mulai dari ketinggian 0 - 1300 meter dari permukaan laut (Sunaryono, 1984). Tanaman cabe menghendaki tanah yang gembur dan subur serta kaya akan humus dengan kisaran $\mathrm{pH}$ antara 5-6. Waktu tanam yang baik adalah pada awal musim kemarau, dengan curah hujan optimal untuk pertumbuhan adalah 100 - $200 \mathrm{~mm}$ per bulan serta kelembaban udara yang cukup tinggi.

Cabe adalah salah satu jenis sayuran penting yang sudah dibudidayakan secara komersil, dan tidak dapat dipisahkan dari kebutuhan seharihari dalam komsumsi rumah tangga (Rukmana, 1996 dan Anonim, 2003). Rasa pedas pada buah cabe disebabkan karena didalamnya banyak mengandung zat capsaicin. Capsaicin banyak terdapat pada biji cabe dan plasenta, yaitu kulit cabe bagian dalam yang berwarna putih tempat melekatnya biji. Rasa pedas tersebut bermanfaat untuk mengatur peredaran darah, memperkuat jantung, nadi dan saraf, mencegah flu dan demam, serta mengurangi nyeri dan encok (Pranata, 1999).

Selain sebagai penyedap masakan cabe mengandung zat-zat gizi yang sangat diperlukan untuk kesehatan manusia. Cabe dikenal kaya akan vitamin, mineral dan karbohidrat serta kandungan zat-zat gizi lain yang cukup tinggi, sehingga dengan komposisi yang lengkap banyak dimanfaatkan sebagai bahan obat tradisional dan penyedap makanan. Saat ini cabe juga banyak digunakan dalam industri farmasi, kosmetik, makanan, minuman dan bahkan saat ini cabe sudah digunakan untuk memperindah taman ataupun sebagai tanaman hias (Ashari 1995; Samsudin, 1982).

Kebutuhan cabe dari tahun ke tahun terus meningkat, ini sejalan dengan meningkatnya jumlah penduduk yang semakin banyak serta berkembangnya serapan dari sektor industri yang menggunakan cabe sebagai bahan baku. Secara umum dikenal dua jenis tanaman cabe yaitu cabe besar ( $C$. annum) dan cabe rawit ( $C$. frutescens). Perbedaan antara cabe besar dan cabe rawit disamping dalam hal bentuk buah, juga dalam hal bentuk pohon, yakni pohon cabe besar pertumbuhannya lebih pendek dan sedikit bercabang, sedangkan cabe rawit bentuk pohonnya banyak bercabang dan relatif lebih tinggi (Samsudin, 1982).

Saat ini pemerintah lewat Departemen Pertanian menjadikan cabe sebagai salah satu dari sepuluh komoditas unggulan hortikultura untuk dikembangkan. Upaya peningkatan produksi cabe sampai saat ini sudah dilakukan baik melalui program intensifikasi maupun ektensifikasi. Produksi dan produktivitas cabe di Propinsi Sulawesi Utara tahun 2004-2007 menurun dari 13.605 ton pada tahun 2004 menjadi 8.523 ton tahun 2007 dengan rata-rata produktivitas 3,1 ton/ha dibandingkan dengan produksi 6-8 ton per ha (Anonim, 2007). Penyebab rendahnya produksi dapat diakibatkan oleh menurunnya tingkat kesuburan tanah, akibat penanaman terus menerus, belum menggunakan pupuk yang berimbang serta adanya serangan hama dan penyakit (Santika, 1995).

Salah satu Organisme Pengganggu Tumbuhan (OPT) penting yang sering menyerang tanaman cabe adalah penyakit antraknosa yang disebabkan oleh jamur Gloeosporium piperatum dan Colletotrichum capsici. Tingkat serangan penyakit ini bervariasi dan dapat menyebabkan terjadinya kerugian 5-65\% (Semangun, 1994). Sebagai OPT penting tanaman cabe penyakit antraknosa ini juga telah menyebabkan kerugian yang sangat berarti bagi petani cabe di Sulawesi Utara. Pada umumnya petani cabe masih sangat kurang pengetahuan tentang penyakit antraknosa serta cara pengendaliannya yang benar.

Penyakit Antraknosa pada tanaman cabe tersebar luas di semua daerah pertanaman cabe di seluruh dunia. Di Indonesia yang beriklim tropis penyakit ini dapat menimbulkan kerugian yang sangat besar seperti di Sumatera, Lampung. Irian Jaya dan daerah lainnya. Dilaporkan bahwa penyakit Antraknosa juga telah ditemukan di berbagai negara seperti Malaysia, Philipina, Amerika, Thailand, Singapura dan Nigeria (Semangun, 1994). 
Penyakit Antraknosa pada cabe disebabkan oleh jamur yang terdiri dari dua jenis yaitu Gloeosporium piperatum Ell. et EV. dan Colletotrichum capsici (Syd.) Budl. Et Bisby. Terdapat empat jenis jamur Colletotrichum yang berasosiasi pada tanaman cabe yaitu : $C$. acutatum, C. gloeosporioides, C. Capsici, dan C. boninese (Zheu, et. al., 2007).

Penelitian ini bertujuan untuk mengetahui patogen penyebab penyakit, distribusi serta insidensi penyakit antraknosa pada beberapa varietas tanaman cabe di Kota Bitung dan Kabupaten Minahasa Propinsi Sulawesi Utara.

Diharapkan penelitian ini dapat memberikan informasi mengenai pathogen penyebab penyakit, distribusi penyakit antraknosa dan insidensinya sehingga dapat diperoleh masukan serta teknik yang efektif dalam usaha pengendaliannya.

\section{METODE PENELITIAN}

Penelitan ini dilaksanakan di Kota Bitung, yakni di Kecamatan Ranowulu, Kecamatan Aertembaga dan Kecamatan Lembeh Selatan dan Kabupaten Minahasa, meliputi Kecamatan Langowan Timur, Kecamatan Tompaso dan Kecamatan Kawangkoan, dalam bentuk penelitian lapangan sedangkan penelitian laboratorium, di Laboratorium Mikrobiologi dan Penyakit Tumbuhan Fakultas Pertanian Unsrat. Penelitian berlangsung selama 3 bulan.

Bahan dan alat yang digunakan dalam penelitian ini adalah : varietas tanaman cabe keriting dan rawit, buah cabe yang terserang penyakit antraknosa, lahan, media PDA, media CLA, antibiotik, aquades, alkohol $70 \%$, plastik bening, petridish, parafilm, tabung reaksi, beker gelas, hot plate, jarum ose, lampu Bunsen, Erlenmeyer, timbangan, pinset, cutter, silet, selotip, autoclave, lainar air flow, light banks, cover gelas, objek gelas, mikroskop, had counter, kamera digital dan alat tulis menulis.

\section{Tahapan Penelitian \\ Di Lapangan}

Penelitian ini menggunakan metode survey atau observasi lapangan secara purposive sampling dengan objek penelitian lahan petani cabe yang sementara berbuah (fase generatif). Varietas yang diamati adalah varietas cabe besar (keriting) dan varietas cabe kecil (cabe putih dan hijau local). Petak pengamatan diambil 5 (lima) unit contoh pada masing-masing kecamatan. Hal-hal yang diamati adalah insidensi atau tingkat kerusakan yang ditimbulkan oleh penyakit antraknosa.

Pengamatan di lapangan adalah untuk menentukan insidensi serangan penyakit antraknosa. Langkah pertama yang dilakukan adalah penentuan lokasi penelitian untuk dilakukan pengamatan. Setiap kecamatan ditentukan satu lokasi kebun yang luasnya kurang lebih 1 ha. Pengambilan sampel dilakukan secara irisan diagonal yang setiap sub-lokasi sampel diambil 10 tanaman. Jadi jumlah tanaman yang diamati pada masing-masing kecamatan adalah sebanyak 50 pohon.

Untuk menetukan insidensi penyakit dari hasil pengamatan ditiap kecamatan dihitung dengan menggunakan rumus insidensi penyakit yaitu:

$$
\mathrm{IP}=\stackrel{\mathrm{n}}{\mathrm{N}} \text {-- } \mathrm{x} 100 \%
$$

Dimana :

$$
\begin{array}{ll}
\mathrm{IP} & =\text { Insidensi Penyakit } \\
\mathrm{n} & =\text { Jumlah Buah Terinfeksi } \\
\mathrm{N} & =\text { Jumlah Buah Yang Diamati }
\end{array}
$$

\section{Di Laboratorium}

Penelitian di laboratorium untuk menentukan jamur patogen penyebab penyakit antraknosa pada buah cabe dengan Postulat Koch.

Pengambilan inang atau tanaman sakit di lapangan dengan mengamati tanaman yang buahnya menunjukkan gejala terserang penyakit antraknosa dengan gejala busuk lunak dan busuk kering. Isolasi; spesimen dibuat potongan-potongan berukuran sekitar $5 \times 5 \mathrm{~mm}$. Pada potongan ini harus terdapat jaringan sehat yang tersambung dengan jaringan sakit dan ditempatkan pada media PDA + AB / antibiotic, diletakkan empat potongan per cawan petri, lalu diberi label dan diletakkan pada light banks (Rondonuwu, 2008). Subkultur, subkultur dilakukan pada media CLA (Carnation 
Leaf Agar). Caranya: ditempatkan 6-8 potongan daun anyelir (carnation) kedalam cawan-cawan kecil berisi media WA selanjutnya dimasukkan juga potongan kecil jamur dari media PDA dan diusahakan berdekatan dengan potongan daun anyelir. Subkultur dilakukan di laminar air flow, kemudian kembali kultur-kultur ini diletakkan pada light banks, dan inkubasikan selama 1-2 minggu. Identifikasi Jamur, identifikasi jamur dari hasil subkultur dilakukan dengan cara pengamatan mikroskopis dan diikuti dengan inokulasi.

\section{HASIL DAN PEMBAHASAN}

\section{Pengamatan Gejala Penyakit}

Buah cabe yang terserang antraknosa mula-mula berbentuk bercak coklat kehitaman yang kemudian meluas menjadi busuk lunak bahkan busuk kering. Gejala ini sama dengan yang ditimbulkan oleh jamur C. capsici seperti yang dikemukakan oleh Semangun (1994). Dari variasi gejala yang tampak, ada yang busuk hanya sebagian baik dipangkal buah, tengah buah maupun ujung buah bahkan ada yang keseluruhan buahnya menjadi busuk sehingga kelihatan kering dan bentuknya keriput (Gambar 1).

\section{Isolasi}

Dari hasil isolasi yang ditumbuhkan pada media PDA + AB didapatkan hasil bahwa dari kedua gejala busuk lunak/basah dan busuk kering mempunyai sifat yang sama, baik warna maupun bentuknya. Setelah diinkubasikan selama dua sampai tiga hari maka pada setiap spesimen dalam cawan-cawan petri keluarlah koloni jamur yang berwarna putih seperti kapas yang berpusat pada specimen dengan membentuk seperti lingkaran.

\section{Subkultur}

Setelah jamur diinkubasikan selama 1-2 minggu maka dalam setiap cawan kecil berisi media CLA mulai tampak dipermukaan potongan daun anyelir massa konidia pada aservulus. Mulamula terdapat bintik-bintik berwarna kehitaman dan kelabu. Selanjutnya dari setiap bintik keluar massa konidia seperti lendir berwarna keputihan, kuning muda dan oranye (Gambar 2 A). Pada akhirnya semua permukaan daun anyelir dipenuhi dengan begitu banyak massa konidia yang bentuknya bergumpal seperti lendir berwarna krem kekuningan (Gambar 2 B).

\section{Identifikasi}

Hasil identifikasi dari kedua gejala yaitu busuk lunak dan busuk kering dengan menggunakan mikroskop menunjukkan karakteristik jamur yang sama. Jamur yang berasosiasi dengan jaringan buah cabe sakit, yakni massa konidia yang diproduksi pada aservulus nampak seperti gumpalan lendir berwarna kuning muda dan lamakelamaan berubah jadi berwarna oranye (Gambar 3A). Pengamatan dengan menggunakan compound microscope didapat hasil konidium bersel satu, hialin dan berbentuk silindris, ujung-ujungnya tumpul (Gambar 3B).

Dengan demikian dari hasil identifikasi jamur penyebab penyakit antraknosa yang dilaksanakan di laboratorium maka diketahui jenis jamur yang menyebabkan penyakit antraknosa pada buah cabe di Propinsi Sulawesi Utara adalah C. gloeosporiodes. Karakteristik ini sesuai dengan yang dikemukakan oleh Benyahia dkk. (2003) bahwa $C$. gloeosporiodes memproduksi banyak sekali konidia pada aservulus-aservulus yang pada awalnya nampak berwarna krem namun kemudian menjadi pink atau salmon tanpa seta. Aservulus dibentuk pada jaringan subepidermis tanaman yang terinfeksi. Konidia berbentuk silindris, bersel satu dan hialin.

\section{Inokulasi}

Setelah dilakukan inokulasi maka gejala infeksi penyakit mulai tampak pada hari ke-3, semua buah yang diinokulasi dengan jamur mengalami perubahan warna pada luka bekas tusukan menjadi coklat kehitaman dan semakin lama makin membesar yang diiringi dengan membusuknya buah. Gejala yang nampak secara visual sama dengan gejala serangan penyakit antraknosa yang ada di lapangan (Gambar 4). Sementara buah yang dijadikan control tidak mengalami infeksi dan pembusukan. 

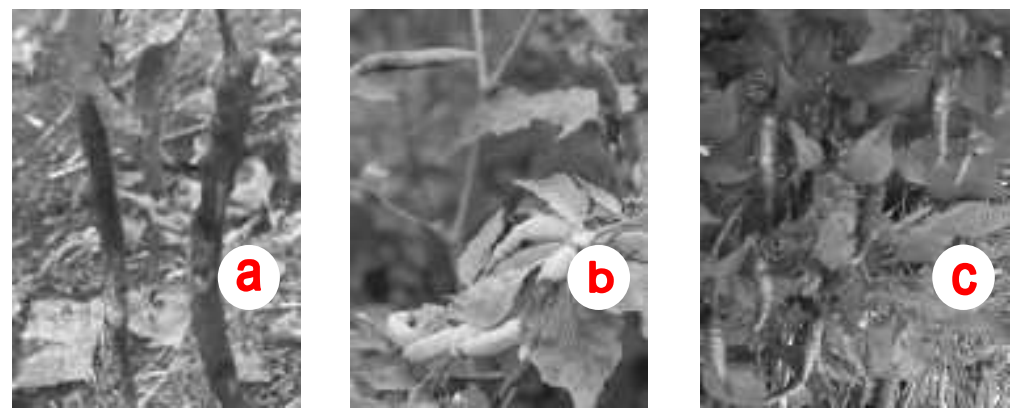

Gambar 1. Gejala Penyakit Antraknosa di Lapangan (a) Varietas cabe keriting; (b) Varietas cabe rawit putih dan (c) Varietas cabe rawit hijau

(Figure 1. Symptoms of Antracnosedisease in Field (a) curl chili; (b) white hot chili and (c) green hot chili)
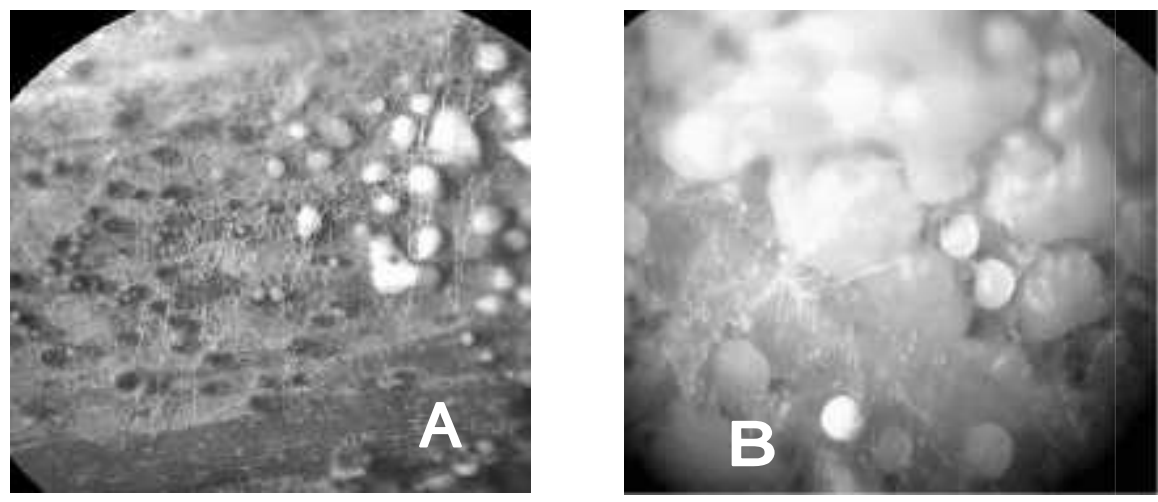

Gambar 2. A. Gejala Awal Massa Konidia pada Aservulus dipermukaan Daun Anyelir. B. Gumpalan Lendir Massa Konidia

(Figure 2. A. Early Symptoms of Mass of Conidia of Acervulum on the Surface Carnation leaf. B. Conidial Mass)

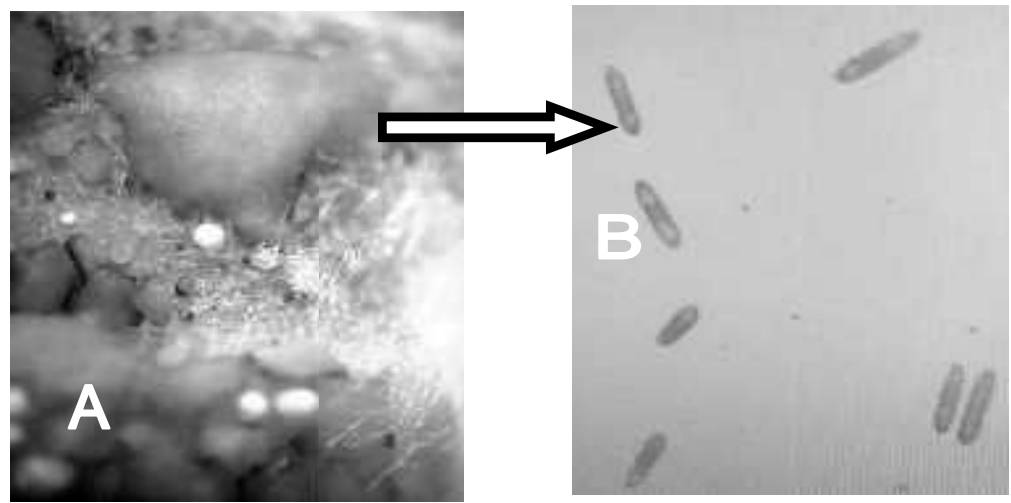

Gambar 3. A. Struktur-struktur pada Aservulus C. gloeosporioides Tubuh Buah dan Massa Konidia yang Keluar dari Tubuh Buah. B. Konidia.

(Figure 3. A. Structures of Acervulus of C. gloeosporioides. B. Conidia)

\section{Insidensi Penyakit Antraknosa}

Berdasarkan pengamatan yang dilaksanakan pada beberapa varietas cabe, yaitu varietas cabe keriting, varietas cabe rawit putih dan varietas cabe rawit hijau pada beberapa kecamatan di Kota Bitung, dan Kabupaten Minahasa dapat dilhat pada Tabel 1. 

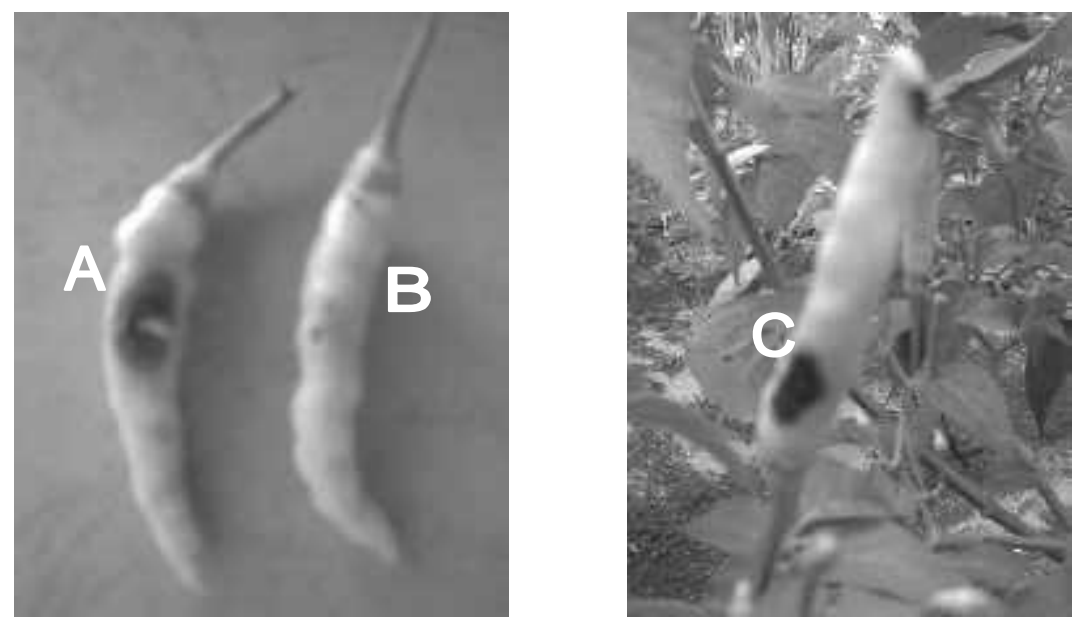

Gambar 4. Perbandingan Gejala Serangan: Setelah 7 Hari di Inokulasi : A. Buah yang di Inokulasi dengan Jamur B. Kontrol C. Infeksi Penyakit di Lapangan

(Figure 4. Different Symptoms of Attack Disease After 7 Days of Inoculation: A. Fruit Inoculated With Fungi, B. Control, and C. Disease Infection in Field)

Tabel 1. Rata-rata Insidensi Penyakit Antraknosa Berdasarkan Varietas Cabe dan Lokasi

(Table 1. The Average Incidence of Antracnose Disease on Different Varities of Chili)

\begin{tabular}{clc}
\hline \multicolumn{1}{c}{ Lokasi } & \multicolumn{1}{c}{ Varietas } & Insidensi Penyakit (\%) \\
\hline Kota Bitung & Cabe keriting & 7,6 \\
Kec. Aertembaga & Cabe rawit putih & 11,2 \\
& Cabe rawit hijau & 10,8 \\
Kec. Lembeh Selatan & Cabe keriting & 14,2 \\
& Cabe rawit putih & 42,4 \\
Kec. Ranowulu & Cabe rawit hijau & 26,4 \\
& Cabe keriting & 9,2 \\
Kabupaten Minahasa & Cabe rawit putih & 12,6 \\
Kec. Langowan Timur & Cabe rawit hijau & 8,9 \\
& & \\
Kec. Tompaso & Cabe keriting & 8,4 \\
& Cabe rawit putih & 12,2 \\
Kec. Kawangkoan & Cabe rawit hijau & 6,3 \\
& Cabe keriting & 18,6 \\
& Cabe rawit putih & 10,3 \\
& Cabe rawit hijau & 4,8 \\
& Cabe keriting & 6,2 \\
& Cabe rawit putih & 9,3 \\
\hline
\end{tabular}

Tabel 2. Rata-rata Insidensi Penyakit Antraknosa Berdasarkan Varietas Di Provinsi Sulawesi Utara (Table 2. The Averages Incidence of Antracnose Disease at Different Varieties at North Sulawesi)

\begin{tabular}{cc} 
Varietas & Insidensi penyakit $(\%)$ \\
\hline Cabe keriting & 9,03 \\
Cabe rawit putih & 16,50 \\
Cabe rawit hijau & 10,13 \\
\hline
\end{tabular}


Eugenia Volume 18 No. 2 Agustus 2012

Tabel 3. Rata-rata Insidensi Penyakit Antraknosa Berdasarkan Lokasi Pengamatan

(Table 3. Average Incidence of Antraknose Disease at Different Locations)

\begin{tabular}{lc}
\multicolumn{1}{c}{ Lokasi } & Insidensi penyakit (\%) \\
\hline Kota Bitung & \\
Kecamatan Aertembaga & 9,86 \\
Kecamatan Lembeh Selatan & 27,66 \\
Kecamatan Ranowulu & 10,23 \\
Kabupaten Minahasa & \\
Kecamatan Langowan Timur & 8,96 \\
Kecamatan Tompaso & 11,23 \\
Kecamatan Kawangkoan & 6,36 \\
\hline
\end{tabular}

Dari Tabel 2 terlihat bahwa rata-rata insidensi penyakit antraknosa pada varietas cabe rawit putih paling tinggi yaitu $16.50 \%$ diikuti varietas cabe rawit hijau $10,13 \%$ dan terendah varietas cabe keriting $9,03 \%$. Penyebab tinggi rendahnya insidensi penyakit sangat dipengaruhi oleh ketahanan varietas, dimana varietas cabe rawit putih lebih peka dibandingkan dengan varietas cabe keriting dan varietas cabe rawit hijau. Kerusakan akibat serangan C. gloeosporioides pada tanaman cabe dipengaruhi oleh faktor patogen, tanaman dan lingkungan. Pada buah cabe yang rentan dan kondisi lingkungan yang sesuai bagi perkembangan pathogen $C$. gloeosporioides dapat menimbulkan kerusakan yang serius. Perbedaan ketahanan dari tiga varietas tanaman cabe tersebut diduga adanya perbedaan kandungan unsur-unsur kimia dari tanaman atau terbentuknya senyawa-senyawa tertentu seperti fitoaleksin pada masing-masing varietas. Hal tersebut pernah dikemukakan oleh Pawirosumarjo (1998) bahwa ketahanan tanaman karet yang diserang oleh C. gloeosporioides dipengaruhi oleh kandungan varietas untuk menghasilkan fitoaleksin lebih banyak dari pada varietas rentan. Dari pengamatan di lapangan varietas cabe rawit putih lokal ini ada dua jenis yaitu warna buah muda berwarna putih polos dan warna putih bercampur ungu. Semangun (1994) mengatakan suhu yang paling baik untuk perkembangan jamur adalah sekitar $32^{\circ} \mathrm{C}$. Sedangkan pembentukan spora (sporulasi) untuk G. piperatum adalah pada suhu $32^{\circ} \mathrm{C}$ dan pada C. gloeosporioides adalah $30^{\circ} \mathrm{C}$. Sementara untuk Kota Bitung, suhu rata-rata pada siang hari $32-33^{\circ} \mathrm{C}$ dan malam hari $28-^{2} 9^{\circ} \mathrm{C}$.
Dengan kisaran suhu seperti ini sangat berpengaruh terhadap perkembangan jamur penyebab penyakit antarknosa.

Dilihat dari lokasi pengamatan di beberapa kecamatan di Kota Bitung dan Kabupaten Minahasa menunjukkan bahwa penyakit ini telah tersebar di semua pertanaman cabe, namun ada beberapa lokasi yang insidensi penyakitnya cukup tinggi seperti di Kecamatan Lembeh Selatan, Kota Bitung mencapai rata rata $27,66 \%$.

\section{KESIMPULAN}

Hasil identifikasi di laboratorium ditemukan jamur penyebab penyakit Antarknosa yang menyerang tanaman cabe di Propinsi Sulawesi Utara adalah dari jenis Colletotrichum gloeosporioides (Penz.) Penz. \& Sacc.in Penz. $(\mathrm{Cg})$.

Insidensi penyakit antraknosa pada tanaman cabe di Propinsi Sulawesi Utara sudah menyebar diseluruh wilayah pengamatan dengan insidensi penyakit tertinggi pada varietas cabe rawit putih $16,50 \%$ diikuti varietas cabe rawit hijau $10,03 \%$ dan terendah adalah varietas cabe keriting $9,03 \%$.

\section{PENGHARGAAN}

Penelitian ini dibiayai dari dana IPM CRSP/USAID, Universitas Sam Ratulangi Tahun Anggaran 2010/2011.

\section{DAFTAR PUSTAKA}


Anonim. 2003 Plant Pathology, http:bugs.bio.

Ratulangi, M.M., dkk. : Diagnosis Dan Insidensi Penyakit Antraknosa assess. IllIIII. IU Ivialel. CUI I.

2007. Kumpulan dasar dan Pedoman

Perlindungan Tanaman. Direktorat Perlindungan Tanaman Pangan. Direktorat Jenderal Tanaman Pangan Departemen Pertanian. Jakarta.

Ashari, S. 1995. Hortikultura Aspek Budaya. Universitas Indonesia Perss. Jakarta

Benyahia, H; A. Smaili; and L. W. Timmer. 2003. Colletotrichum gloeosporioides Causing Withertip on Twigs and Tear Stain on Fruit of Citrus in Morocco. http://laurel.nal.usda.gov/agnic/pmp/2003/ cgc062603.html. 18 Maret 2011

Pranata, F. 1999. Agribisnis Cabai Hibrida. Penebar Swadaya. Jakarta.

Rondonuwu, F. B. 2008. Kajian Penyakit Busuk Batang Panili (Vanilla planifolia Andrews) di Minahasa. Tesis. Pascasarjana Universitas Sam Ratulangi Manado.
Rukmana, 1996. Agribisnis Cabai Hibrida. Penebar Swadaya. Jakarta.

Santika, 1995. Agribisnis Cabai Hibrida. Penebar Swadaya. Jakarta.

Samsudin, S 1982. Bertanam Cabe. Bina Cipta. Jakarta.

Semangun, H. 1994. Penyakit-Penyakit Tanaman Hortikultura di Indonesia. Gadjah Mada University Press. Yogyakarta.

Sunaryono, H. 1984. Kunci Bercocok Tanam SayurSayuran Penting di Indonesia. Sinar Baru. Bandung.

Zheu, Z.; J. Chen and T. Wang. 2007. Application of ITS-RFLP Analysis for Identifying Colletotrichum Species Associated with Pepper Anthracnose in Taiwan. http://www.avrdc.org/anthracnose/index. html. 27 April 2011. 
